Article

\title{
Origin of Compositional Diversity of Marine Tephra during the Late Middle Pleistocene B-KY1 Baekdusan Volcanic Eruption
}

\author{
Jong-Hwa Chun ${ }^{1, *(D)}$ and Daekyo Cheong ${ }^{2}$ \\ 1 Petroleum \& Marine Research Division, Korea Institute of Geoscience \& Mineral Resources (KIGAM), \\ Daejeon 34132, Korea \\ 2 Department of Geology, Kangwon National University, Chuncheon 24235, Korea; dkcheong@kangwon.ac.kr \\ * Correspondence: jhchun@kigam.re.kr; Tel.: +82-042-868-3328
}

Received: 22 May 2020; Accepted: 23 June 2020; Published: 28 June 2020

check for updates

Featured Application: Explosive volcanic eruption, Marine tephra.

\begin{abstract}
The focus of this study was the Baekdusan-Kita 1 (B-KY1) eruption during the late Middle Pleistocene. We identified B-KY1 tephra between the Toya and Aso-1 tephras in the ODP 794A core from the Japan Basin of the East Sea/Japan Sea. The stratigraphic position of the B-KY1 tephra correlated exactly with the first B-KY1 to be identified, in the 20EEZ-1 core from the Kita-Yamato Trough. However, B-KY1 tephra in the ODP 794A core showed a wide range of geochemical compositions. The textural characteristics of B-KY1 tephra in the ODP 794A core was characterized by higher content of fine-grained bubble-wall shards than that of the B-KY1 tephra in the 20EEZ-1 core. The difference in B-KY1 tephra between the two coring sites may reflect shifts in wind direction during volcanic eruptions. We refined the eruption age of the B-KY1 tephra by examining distinct sedimentary facies related to the start of the penultimate deglaciation of this region at ca. 135 $\mathrm{ka}$. The findings of this study suggest that the compositional diversity of B-KY1 tephra may have been influenced by subsequent mixing of comendite and comenditic trachyte magma with injected pantelleritic magma during the late Middle Pleistocene Baekdusan volcanic eruption.
\end{abstract}

Keywords: Baekdusan tephras; B-KY1 tephra; late Middle Pleistocene; injected pantelleritic magma

\section{Introduction}

In the mid-10th century, Baekdusan (also known as Changbaishan in Chinese) experienced a VEI-7 explosive volcanic eruption, which produced large amounts of B-Tm tephra [1,2]. Only a few terrestrial pyroclastic deposits found on Baekdusan have been dated to within 17,000 years [3]. Many studies of the Millennium Eruption, as B-Tm eruption that occurred in $946 \mathrm{CE}$, have focused on defining the date of this eruption due to its major historical, chronological, and climatic implications [4-14]. Recently, B-Tm tephra was found in Lake Ichi-no-Megata and Lake Suigetsu in Japan $[8,9,15]$ (Figure 1). No studies have reported terrestrial pyroclastic deposits intercalated with effusive Baitoushan I-III trachyte or comendite lava flows during the last Pleistocene and Pliocene. However, distal tephras transported by explosive volcanic eruptions of Baekdusan have been identified in marine sediments of the East Sea/Japan Sea and Pacific Ocean, as well as in terrestrial sedimentary deposits on the islands of Japan (Figure 2). B-Tm and B-Og (ca. $448 \mathrm{ka}$ ) tephras [16,17] were first identified in sedimentary deposits from Tomakomai and the Oga Peninsula in Japan, respectively (Figure 1). Alkali Baekdusan tephras are easily distinguished from sub-alkali tephras derived from Japanese volcanoes (Figure 1). The distribution patterns of 946 CE B-Tm tephra have been well documented in marine sediments 
collected from the East Sea using piston corers with a barrel length of $<7 \mathrm{~m}$. A Middle Pleistocene B-Og tephra layer [16] has been identified only in the ODP 794A long-core sediments collected at about $14 \mathrm{~m}$ below the seafloor (Figure 1). B-V (ca. $24.5 \mathrm{ka}$ ) and B-J (ca. $51.5 \mathrm{ka}$ ) tephra layers constructed by millennial-scale interstadial paleoclimatic fluctuation records are distinguished by their dark/light sediment patterns [18-20] (Figure 2). The distribution pattern of B-J tephra suggests that seasonal westerly winds influenced atmospheric transport of the eruption plume through the stratosphere during the eruption $[18,21]$. The trajectory of the B-J eruption plume extended further southward than that of the B-Tm eruption (Figure 1).

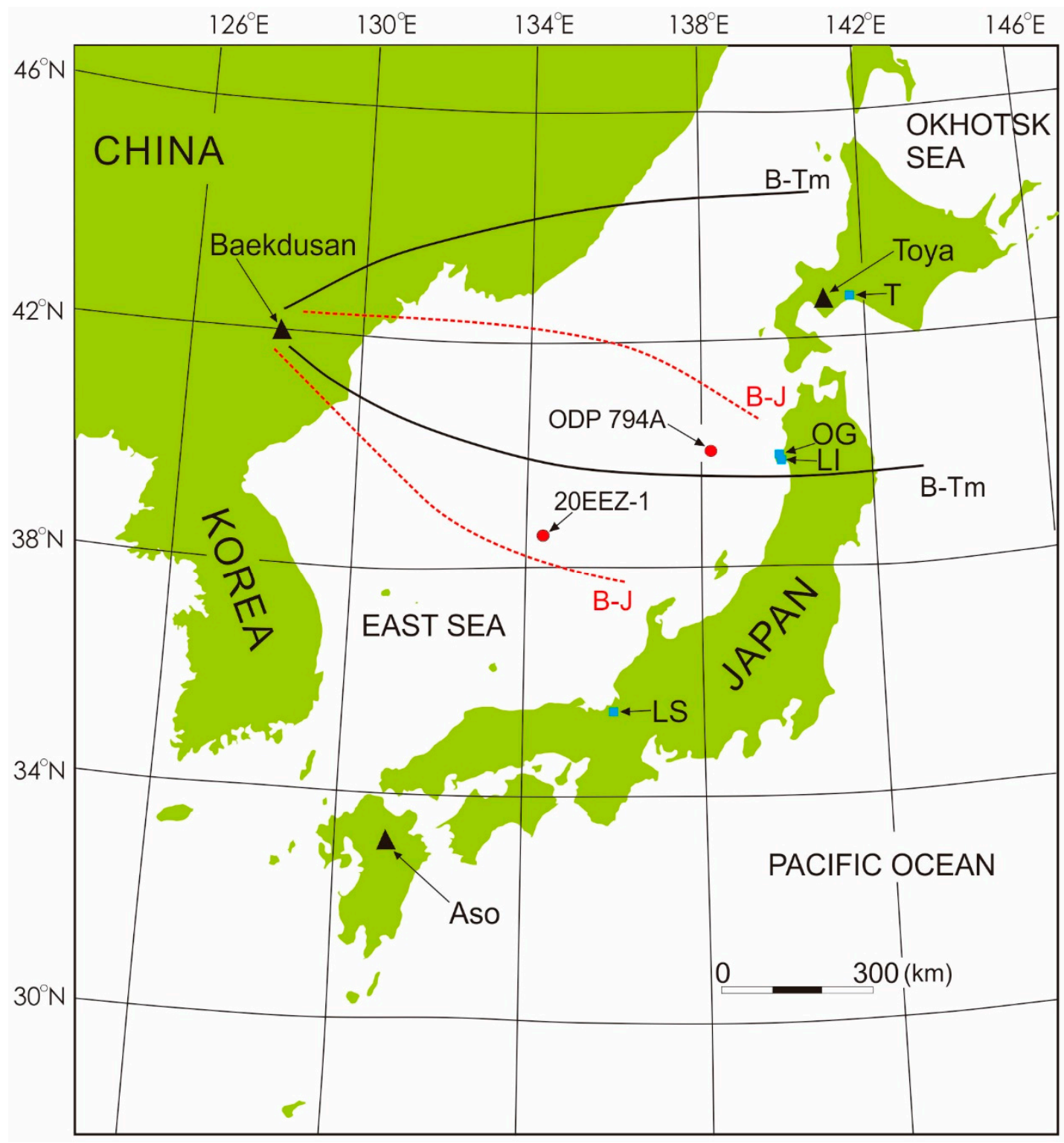

Figure 1. Map of coring sites and source volcanoes in the East Sea/Japan Sea. Solid black line: trajectory of the B-Tm tephra (Adapted from [1]), Dotted red line: trajectory of the B-J tephra (Adapted from [18]), Solid black triangles: Source volcanoes in this study, Solid red circles: Coring sites in this study. Blue squares: Sampling sites in Japanese island. T: Tomakomai, OG: Oga Peninsular, LI: Lake Ichi-no-Megata, LS: Lake Suigetsu.

B-Sado (ca. $67.6 \mathrm{ka}$ ) and B-Ym (ca. $85.8 \mathrm{ka}$ ) tephras were identified by instrumental neutron activation analysis (INAA) of marine sediments [20,22], revealing an invisible tephra layer of micro-sized cryptotephra (Figure 2). B-KY1 (ca. $130 \mathrm{ka}$ ) and B-KY2 (ca. $196 \mathrm{ka}$ ) tephras have been reported in marine 
sediments from a flat hill in the Kita-Yamato Trough [23]; these represent the southernmost visible Baekdusan tephras identified (Figure 2). Many marine cores obtained from the Ulleung Basin and South Korea Plateau in central to southern East Sea contain no visible Baekdusan tephra layers [23-26]. Recently, analysis of the zircon age (U-Th) distribution of terrestrial pyroclastic deposits from the Millennium Eruption revealed multiple age components at $11.3 \pm 1.3 \mathrm{ka}$, ca. $110 \mathrm{ka}$, and $230 \mathrm{ka}$ [27]. Other zircons (U-Th) from $0.3 \mathrm{ka}$ pyroclastic deposits have been dated to $2.6 \pm 1.8 \mathrm{ka}$, ca. $130 \mathrm{ka}$, and $>230 \mathrm{ka}[11,28]$. Based on the zircon isochron ages of terrestrial pyroclastic deposits on Baekdusan, episodic magma generation may have occurred at 110-130 ka and ca. 230 ka during the Pleistocene.

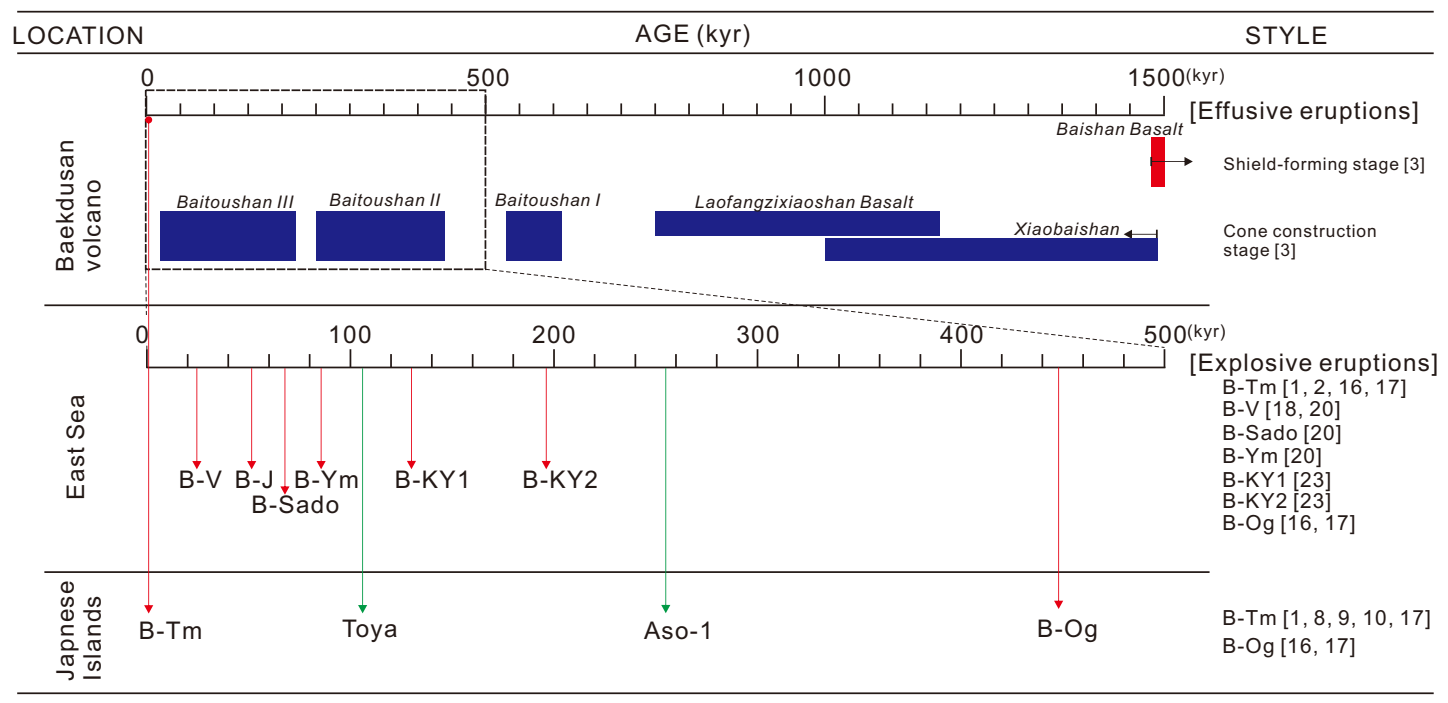

Figure 2. Volcanic history of Baekdusan. The shield-forming and cone construction stages originated from effusive eruptions of Baekdusan (Data from [3]). Eight tephra layers in East Sea marine sediments and two tephra layers in Japanese island sediments caused by Plinian eruptions of Baekdusan (Data from [1-3,8-10,16-18,20,22,23]). Toya and Aso-1 tephra layers (green arrows) in the ODP 794A core were transported by explosive volcanic eruptions of Japanese volcanoes (Data from [29]).

The main objective of this study was to report the identification of a newly discovered Middle Pleistocene B-KY1 tephra from ODP 794A core about $900 \mathrm{~km}$ from Baekdusan, which is the most northerly tephra identified to date. Other cores cannot be used to identify Middle Pleistocene Baekdusan tephras due to their short core length $(<7 \mathrm{~m})$. A previous study reported the stratigraphic positions of Toya (ca. $106 \mathrm{ka}$ ) and Aso-1 (ca. $255 \mathrm{ka}$ ) tephras in the ODP 794A core [16,29]. We analyzed the major elements and backscattered electron images (BSEIs) of the Toya, B-KY1, and Aso- 1 tephras, and sedimentary facies related to millennial scale paleoclimatic fluctuation or eustatic sea level change records $[23,25,26,29]$. The major element data provide a geochemical fingerprint for the tephras, and BSEIs allow their textural characteristics to be determined, reflecting the explosive eruption and long-range transportation distance from source volcanoes. Precise stratigraphic correlation with chronologic marine events was used to refine the age of B-KY1 tephra. The findings of this study will contribute to reconstruction of the eruption history of Baekdusan during the late Middle Pleistocene.

\section{Geological and Physiographical Settings}

Baekdusan (elevation $2774 \mathrm{~m}$ ) and its caldera lake (Lake Cheonji) straddle the border between North Korea and China. Baekdusan is affected by intraplate volcanism due to large mantle wedge within the upper mantle above the stagnant subducting Pacific slab [30-35]. P-wave velocity tomography has revealed upwelling of hot and wet asthenospheric materials beneath the Baekdusan volcano; these materials originated from the flattened stagnant Pacific slab between the mantle transition zone $(>400 \mathrm{~km})$ and lower mantle $(<660 \mathrm{~km})$ beneath northeastern Asia [32,36,37]. The stratigraphy of the 
Baekdusan stratovolcano is divided into a gentle effusive basaltic shield-forming stage, steep effusive trachytic cone construction stage, and explosive volcanic eruption stage (Figure 2) [3,5,38]. The effusive shield-forming stage [3] began with the deposition of Naitoushan basalt (22.64-15.6 Ma), followed by the deposition of Toudao basalt (5.02-2.35 Ma) and Baishan basalt (1.66-1.48 Ma). The gentle slope $\left(<4^{\circ}\right)$ of Baishan basalt contributed $<2000 \mathrm{~m}$ to the elevation of Baekdusan [38]. Cyclic effusive eruptions of trachyte and comendite cone material [3] led to the deposition Xianbaishan trachyandesite and trachyte (1.49-1.0 Ma), Baitoushan I trachyte (0.61-0.53 Ma), Baitoushan II trachyte with Laohudong basalt (0.44-0.25 Ma), Baitoushan III trachyte and comendite lava (0.22-0.02 Ma). However, explosive volcanic eruptions of Baekdusan formed distant pyroclastic deposits (Qixiangzhan comendite lava and pyroclasts) dated to within $17 \mathrm{ka}$ [3]. Yellow rhyolitic ignimbrite near the caldera Lake Cheonji has been dated to within 4-5 ka, during a pre-caldera eruption [3]. The massive Millennium Eruption of Baekdusan in $946 \mathrm{CE}[8,9,12]$ produced large amounts of B-Tm, and the most recent volcanic eruption was a comendite phreatomagmatic eruption in $1903 \mathrm{CE}[3,13,38]$.

Studies using marine tephras in the East Sea have reconstructed the explosive volcanic history of Baekdusan (Figure 2). B-Tm (946 CE), B-V (ca. $24.5 \mathrm{ka}$ ), B-J (ca. $51.5 \mathrm{ka}$ ), B-Sado (ca. $67.6 \mathrm{ka})$, B-Ym (ca. $85.8 \mathrm{ka}$ ), 20EEZ-1 core B-KY1 (ca. $130 \mathrm{ka}$ ), B-KY2 (ca. $196 \mathrm{ka}$ ), and B-Og (ca. $448 \mathrm{ka}$ ) tephras were produced by explosive eruptions of Baekdusan $[1,2,16,18-20,23]$; their distribution patterns were influenced by eruption intensity and the strength of westerly winds [18,21]. The preservation of tephra layers within marine sediments in is controlled by prevailing bottom currents and bioturbation by benthic organisms. Bottom water circulation and the oxygen level are higher at highstand than at lowstand in the East Sea [26]; thus, marine tephras deposited during lowstand ("dark laminated deposits") are better preserved [18,19].

\section{Materials and Methods}

Between the Toya (ca. $106 \mathrm{ka}$ ) and Aso-1 (ca. $255 \mathrm{ka}$ ) tephras, which have been identified stratigraphically, a visible B-KY1 tephra layer was identified in the ODP 794A core (Figure 3). The major elements $\left(\mathrm{SiO}_{2}, \mathrm{TiO}_{2}, \mathrm{Al}_{2} \mathrm{O}_{3}, \mathrm{FeO}^{*}, \mathrm{MnO}, \mathrm{MgO}, \mathrm{CaO}, \mathrm{Na}_{2} \mathrm{O}\right.$, and $\left.\mathrm{K}_{2} \mathrm{O}\right)$ of the three tephras were identified using an electron microprobe analyzer (JXA8900; JEOL Co.) at the Geological Survey of Japan (GSJ), National Institute of Advanced Industrial Science and Technology (AIST). Subsamples of fine-grained hemipelagic particles were removed from tephra samples by submersion in an ultrasonic bath. Dried tephra grains were mounted on glass using epoxy resin, which solidified after 3 days at room temperature. Thin sections were polished using increasingly fine diamond paste (300 mesh to $1 \mu \mathrm{m})$. Electron microprobe analyses were performed at an acceleration voltage of $15 \mathrm{kV}$, beam current of $12 \mathrm{nA}$, and beam size of $10 \mu \mathrm{m}$. The peak counting time of all major elements was $10 \mathrm{~s}$, and that for the background was $5 \mathrm{~s}$. Prior to analysis of the three tephras, the microprobe was calibrated to major elements using GSJ standard samples and well-known working standards (sub-alkali AT and alkali U-Oki tephras). Geochemical elements of B-KY1 tephra were plotted against well-known Aso-4, Toya, Aso-1, B-J, B-Sado, B-Ym, B-KY1 (20EEZ-1 core), B-KY2, B-Og tephras using major elements normalized to $100 \mathrm{wt} . \%$. BSEIs of tephras were used to measure grain size and textural characteristics based on the classification of glass shards $[39,40]$. The grain size and constituent composition of the tephra were used to characterize the explosiveness, transport distance, and type of eruption of the source volcanoes. Photographs and X-radiographs of the ODP 794A and 20EEZ-1 cores were interpreted by comparing the sedimentary facies to records of East Sea eustatic sea-level variation [41]. Distinct sedimentary facies related to the B-KY1 tephra were interpreted for stratigraphic correlation and age model construction. 


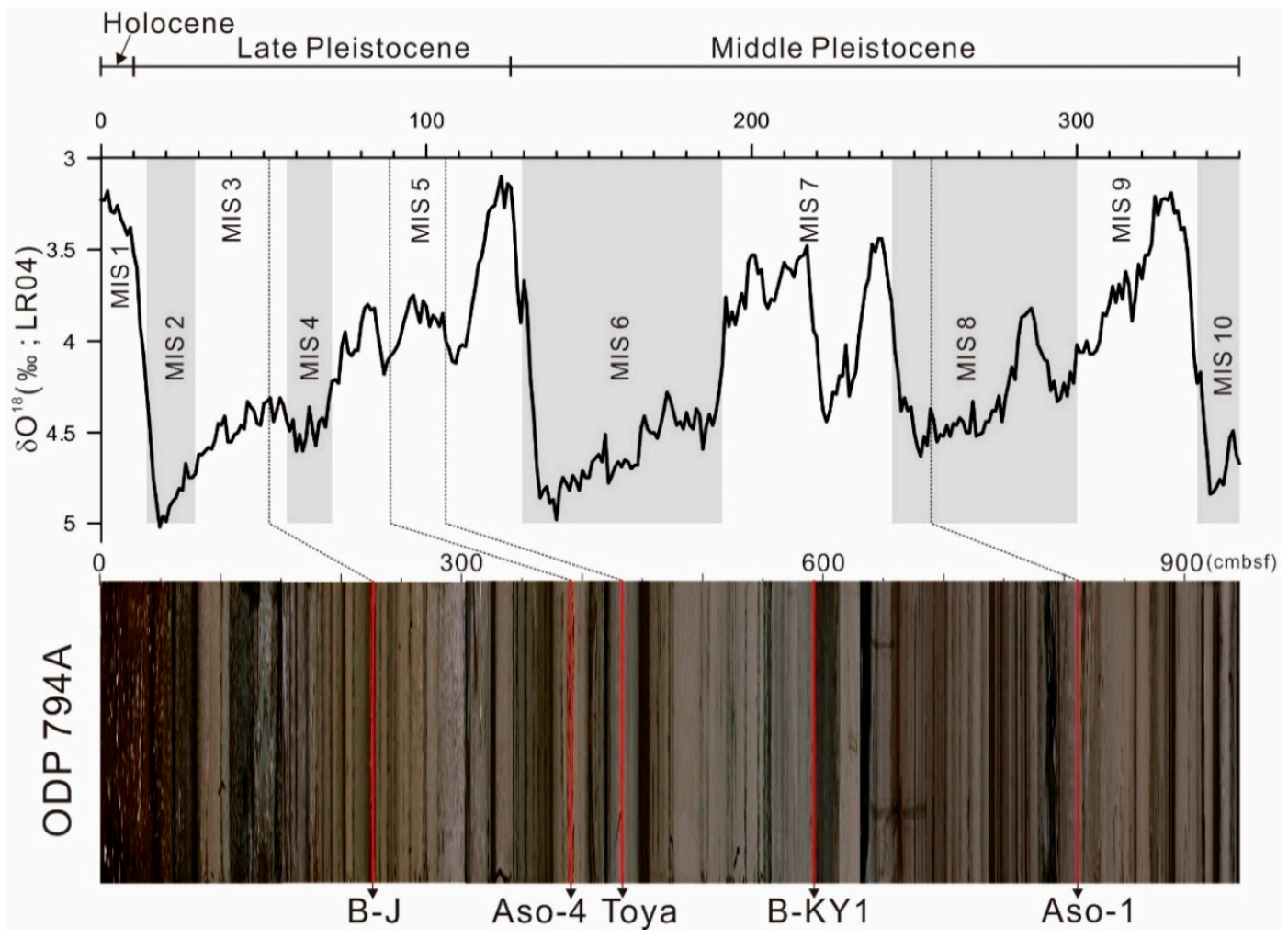

Figure 3. Stratigraphic position of the B-KY1 tephra layer between the Toya and Aso-1 tephra layers in the ODP 794A core (Photographs adapted from [41]).

\section{Results}

\subsection{Late Pleistocene Toya Tephra}

Stratigraphically identified Toya tephra was found within thick-bedded, light-colored bioturbated mud (LBM) at an interval of $428.2-429.3 \mathrm{~cm}$ below the seafloor (cmbsf; $1 \mathrm{H}-4,14.2-15.3 \mathrm{~cm}$ ) in the ODP 794A core (Figure 4B). Gray Toya tephra mainly consisted of pumice shards, with minor bubble-wall shards and phenocrysts (Figure 5A; Table 1). The maximum grain sizes of the pumice shards, bubble-wall shards, and phenocrysts ranged from 90 to $120 \mu \mathrm{m}$, and the degree of vesicularity and stretching of the pumice shards ranged from low to moderate (Figure 5A; Table 1).

Table 1. Textural characteristics of the three tephras in the ODP 794A core and B-KY1 tephra in the 20EEZ-1 core in the East Sea/Japan Sea. Bs: bubble-wall shards, Ps: pumice shards, Ph: phenocrysts.

\begin{tabular}{|c|c|c|c|c|}
\hline Tephra & $\begin{array}{c}\text { Textural } \\
\text { Composition }\end{array}$ & $\begin{array}{c}\text { Degree of } \\
\text { Vesicularity }\end{array}$ & $\begin{array}{l}\text { Degree of } \\
\text { Stretching }\end{array}$ & $\begin{array}{l}\text { Maximum } \\
\text { Grain Size } \\
\quad(\mu \mathrm{m})\end{array}$ \\
\hline $\begin{array}{c}\text { Toya in the ODP } \\
\text { 794A core }\end{array}$ & $\mathrm{Ps}>>\mathrm{Bs}>\mathrm{Ph}$ & low to moderate & low to moderate & $\begin{array}{c}\text { Bs: 120, Ps: } 100 \text {, } \\
\text { Ph: } 90\end{array}$ \\
\hline $\begin{array}{l}\text { B-KY1 in the ODP } \\
794 \mathrm{~A} \text { core }\end{array}$ & $\mathrm{Bs} \cong \mathrm{Ps}>\mathrm{Ph}$ & moderate to high & moderate to high & $\begin{array}{l}\text { Bs: } 180, \text { Ps: } 130 \text {, } \\
\text { Ph: } 130\end{array}$ \\
\hline $\begin{array}{c}\text { B-KY1 in the } \\
\text { 20EEZ-1 core [23] }\end{array}$ & Ps $>$ Bs $>\mathrm{Ph}$ & moderate to high & moderate to high & $\begin{array}{l}\text { Bs: } 210, \text { Ps:170, } \\
\text { Ph: } 150\end{array}$ \\
\hline $\begin{array}{l}\text { Aso- } 1 \text { in the ODP } \\
794 \text { A core }\end{array}$ & Bs $>>\mathrm{Ph}>$ Ps & low to moderate & moderate to high & $\begin{array}{c}\text { Bs: 250, Ps: } 140 \text {, } \\
\text { Ph: } 140\end{array}$ \\
\hline
\end{tabular}



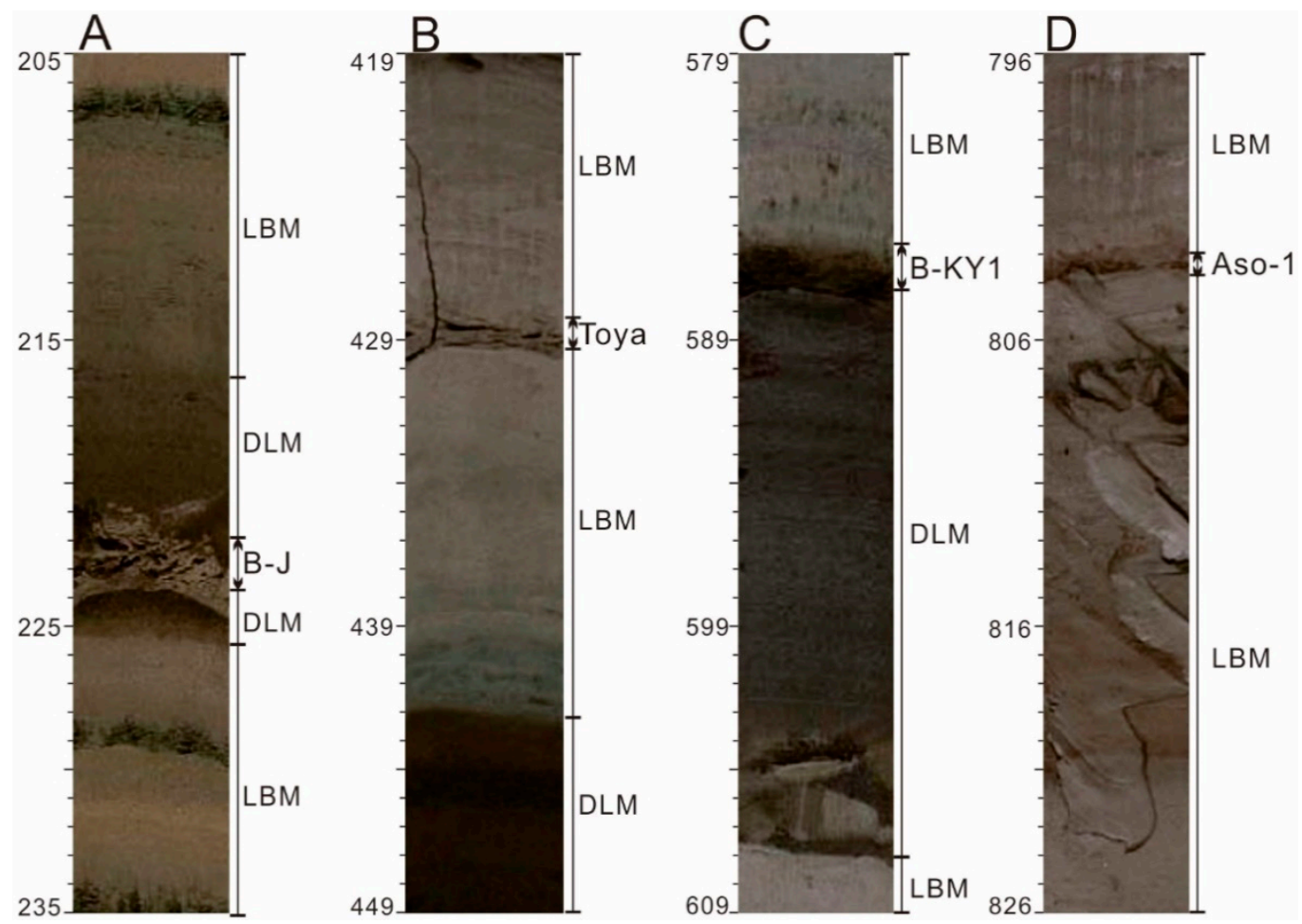

Figure 4. Photographs of tephra layers recovered from ODP 794A core in the Japan Basin of the East Sea/Japan Sea. (A): B-J, (B): Toya, (C): B-KY1, and (D) Aso-1 (Photographs adapted from [41]).

The $\mathrm{SiO}_{2}$ content ranged from 78.25 to $79.10 \mathrm{wt}$. $\%$ and total alkali content $\left(\mathrm{Na}_{2} \mathrm{O}+\mathrm{K}_{2} \mathrm{O}\right)$ ranged from 5.35 to $7.17 \mathrm{wt.} \%$ (Table 2). Toya tephra plotted within sub-alkali rhyolite in the total alkalis versus silica (TAS, [42]) diagram (Figure 6). FeO* content was $<1$ wt.\% (0.72-0.95 wt.\%). The CaO content was low (0.28-0.60 wt.\%) (Table 2).
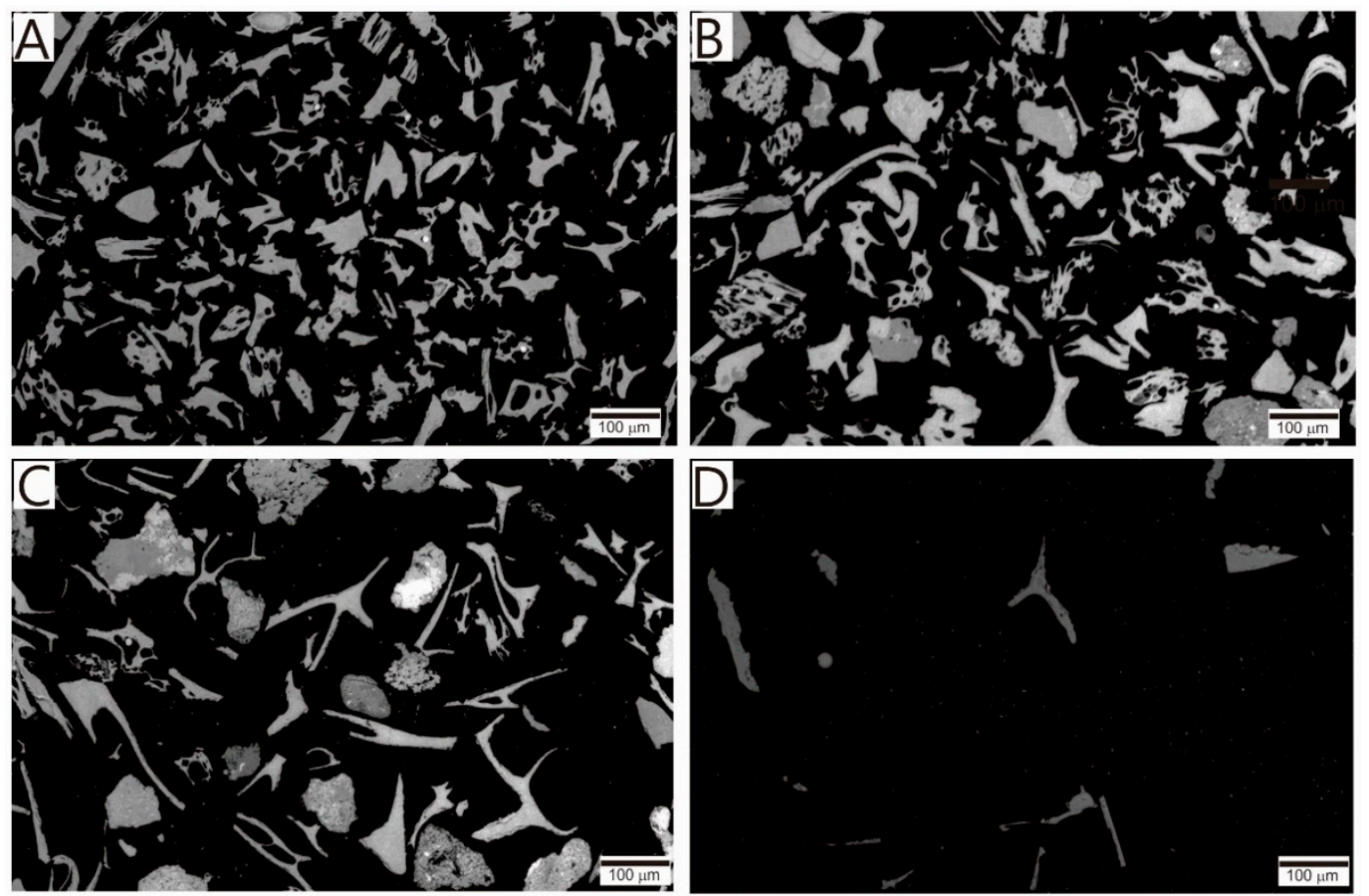

Figure 5. Backscattered electron images of tephra samples from ODP 794A core in the Japan Basin of the East Sea/Japan Sea. (A): Toya, (B): B-KY1, (C): Aso-1, and (D): Aso-4. 
Table 2. Major elements of Toya, B-KY1, and Aso-1 tephra samples from the ODP 794A core. Normalized to 100 wt.\%. FeO*: Total Iron. cmbsf: cm below seafloor.

\begin{tabular}{|c|c|c|c|c|c|c|c|c|c|c|}
\hline $\begin{array}{l}\text { Depth } \\
\text { (cmbsf) }\end{array}$ & $\mathrm{SiO}_{2}$ & $\mathrm{TiO}_{2}$ & $\mathrm{Al}_{2} \mathrm{O}_{3}$ & $\mathrm{FeO}^{*}$ & $\mathrm{MnO}$ & $\mathrm{MgO}$ & $\mathrm{CaO}$ & $\mathrm{Na}_{2} \mathrm{O}$ & $\mathrm{K}_{2} \mathrm{O}$ & Tephra \\
\hline \multirow{14}{*}{$428.2-429.3$} & 78.82 & 0.09 & 12.99 & 0.79 & 0.07 & 0.04 & 0.34 & 4.10 & 2.75 & \multirow{14}{*}{ Toya } \\
\hline & 78.67 & 0.16 & 13.18 & 0.81 & 0.14 & - & 0.36 & 3.80 & 2.88 & \\
\hline & 78.51 & - & 13.31 & 0.80 & 0.08 & 0.02 & 0.33 & 4.17 & 2.79 & \\
\hline & 79.06 & 0.11 & 13.44 & 0.88 & 0.05 & 0.01 & 0.29 & 3.22 & 2.94 & \\
\hline & 78.55 & 0.08 & 13.38 & 0.81 & 0.06 & 0.01 & 0.32 & 4.11 & 2.69 & \\
\hline & 79.83 & 0.07 & 13.45 & 0.85 & 0.09 & 0.03 & 0.33 & 2.65 & 2.70 & \\
\hline & 78.09 & 0.02 & 13.46 & 0.89 & 0.09 & 0.07 & 0.34 & 4.39 & 2.65 & \\
\hline & 79.02 & 0.09 & 13.76 & 0.86 & 0.07 & 0.04 & 0.36 & 3.01 & 2.81 & \\
\hline & 78.78 & 0.07 & 12.90 & 0.81 & 0.12 & 0.05 & 0.34 & 3.73 & 3.19 & \\
\hline & 79.37 & 0.08 & 12.95 & 0.85 & 0.09 & 0.04 & 0.30 & 3.84 & 2.47 & \\
\hline & 78.25 & 0.09 & 13.53 & 0.84 & 0.12 & - & 0.34 & 3.44 & 3.39 & \\
\hline & 78.31 & 0.20 & 13.32 & 0.79 & 0.08 & - & 0.28 & 4.17 & 2.86 & \\
\hline & 78.25 & 0.05 & 13.38 & 0.72 & 0.09 & - & 0.34 & 3.94 & 3.23 & \\
\hline & 79.10 & - & 12.74 & 0.95 & 0.08 & - & 0.28 & 3.88 & 2.97 & \\
\hline \multirow{14}{*}{$585.6-587.2$} & 75.14 & 0.23 & 9.17 & 5.91 & 0.12 & - & 0.22 & 5.02 & 4.18 & \multirow{14}{*}{ B-KY1 } \\
\hline & 75.08 & 0.15 & 9.39 & 6.00 & 0.11 & - & 0.21 & 4.83 & 4.24 & \\
\hline & 73.88 & 0.10 & 10.51 & 5.79 & 0.15 & - & 0.35 & 4.71 & 4.50 & \\
\hline & 72.41 & 0.03 & 11.86 & 5.48 & 0.13 & - & 0.48 & 5.21 & 4.40 & \\
\hline & 73.69 & 0.16 & 11.53 & 5.61 & 0.15 & - & 0.44 & 3.90 & 4.50 & \\
\hline & 70.60 & 0.15 & 13.28 & 5.20 & 0.15 & 0.02 & 0.62 & 5.38 & 4.60 & \\
\hline & 73.26 & 0.07 & 11.26 & 6.05 & 0.14 & - & 0.63 & 4.23 & 4.36 & \\
\hline & 74.96 & 0.22 & 9.24 & 5.81 & 0.13 & 0.04 & 0.24 & 5.06 & 4.29 & \\
\hline & 75.36 & 0.12 & 9.20 & 5.75 & 0.13 & - & 0.22 & 4.90 & 4.32 & \\
\hline & 67.53 & 0.22 & 15.15 & 5.30 & 0.16 & 0.09 & 1.00 & 5.34 & 5.21 & \\
\hline & 68.63 & 0.20 & 15.50 & 5.44 & 0.14 & 0.09 & 0.97 & 3.67 & 5.35 & \\
\hline & 68.47 & 0.27 & 15.06 & 5.37 & 0.19 & 0.05 & 0.89 & 4.37 & 5.32 & \\
\hline & 66.59 & 0.16 & 15.74 & 5.54 & 0.15 & 0.08 & 1.09 & 5.47 & 5.17 & \\
\hline & 67.68 & 0.22 & 15.76 & 5.45 & 0.13 & 0.12 & 1.06 & 4.30 & 5.29 & \\
\hline \multirow{14}{*}{$802.9-803.7$} & 69.91 & 0.23 & 16.32 & 2.73 & 0.08 & 0.54 & 1.75 & 3.63 & 4.82 & \multirow{14}{*}{ Aso-1 } \\
\hline & 70.16 & 0.34 & 16.26 & 2.64 & 0.10 & 0.53 & 1.85 & 3.45 & 4.68 & \\
\hline & 69.87 & 0.28 & 16.13 & 2.59 & 0.13 & 0.52 & 1.92 & 3.54 & 5.03 & \\
\hline & 69.91 & 0.22 & 16.48 & 2.73 & 0.11 & 0.57 & 1.86 & 2.98 & 5.14 & \\
\hline & 69.77 & 0.32 & 16.25 & 2.85 & 0.07 & 0.52 & 1.79 & 3.57 & 4.86 & \\
\hline & 69.71 & 0.23 & 16.23 & 2.73 & 0.08 & 0.55 & 1.85 & 3.70 & 4.93 & \\
\hline & 69.89 & 0.17 & 16.25 & 2.64 & 0.05 & 0.55 & 1.82 & 3.77 & 4.86 & \\
\hline & 70.60 & 0.23 & 16.47 & 2.83 & 0.06 & 0.53 & 1.93 & 2.49 & 4.85 & \\
\hline & 70.49 & 0.17 & 16.03 & 2.59 & 0.14 & 0.59 & 1.77 & 3.36 & 4.86 & \\
\hline & 70.62 & 0.33 & 15.93 & 2.68 & 0.04 & 0.58 & 1.73 & 3.26 & 4.83 & \\
\hline & 70.37 & 0.30 & 16.04 & 2.71 & 0.03 & 0.52 & 1.77 & 3.39 & 4.87 & \\
\hline & 70.36 & 0.41 & 16.09 & 2.47 & 0.06 & 0.47 & 1.89 & 3.31 & 4.93 & \\
\hline & 69.68 & 0.29 & 16.23 & 2.62 & 0.07 & 0.53 & 1.94 & 3.59 & 5.06 & \\
\hline & 69.94 & 0.21 & 15.98 & 2.83 & 0.06 & 0.57 & 1.90 & 3.52 & 5.01 & \\
\hline
\end{tabular}




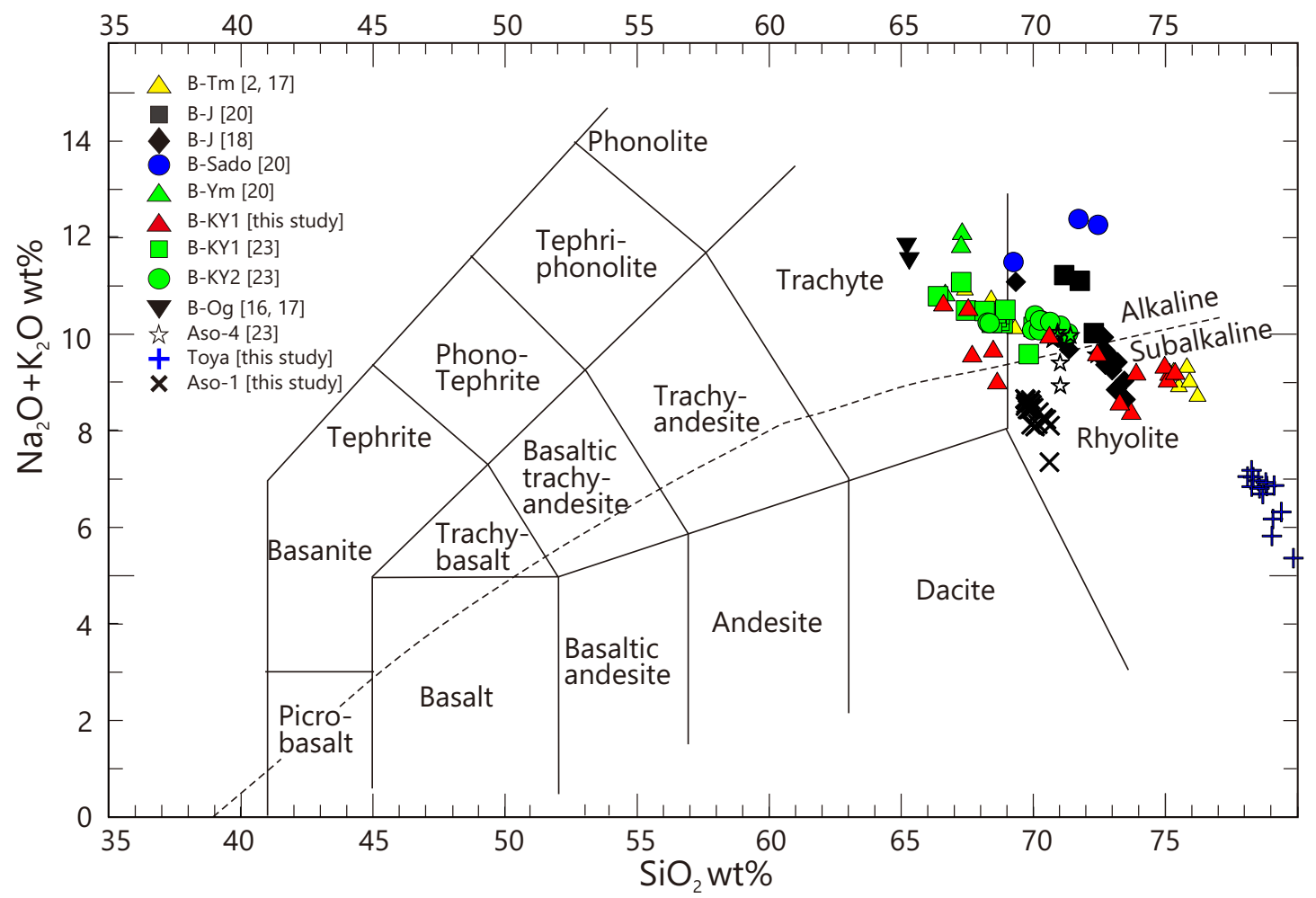

Figure 6. Total alkali versus silica (TAS) diagram (Classification diagram adapted from [42]) of Baekdusan tephra samples and other Japanese tephra samples from ODP 794A core (Data from $[2,16-18,20,23])$.

\subsection{Late Middle Pleistocene B-KY1 Tephra between Toya and Aso-1 Tephras}

B-KY1 tephra was newly identified between the Toya and Aso-1 tephras in ODP 794A core at an interval of 585.6-587.2 cmbsf (1H-5, 21.6-23.2 cm) (Figure 4). A pale brownish B-KY1 tephra was observed to directly overlie dark laminated mud (DLM), with a sharp boundary (Figure 4C). The upper boundary of the B-KY1 tephra diffused into the overlying LBM (Figure 4). The stratigraphic position and color of B-KY1 tephra in the ODP 794A core correlated exactly with the B-KY1 tephra in the 20EEZ-1 core [23]. B-KY1 tephra in the ODP 794A core consisted of pumice shards and bubble-wall shards, with minor phenocrysts (Figure 5B; Table 1). The compositions of pumice shards and bubble-wall shards were similar in B-KY1 tephra in the ODP 794A core. The maximum grain size of bubble-wall shards $(180 \mu \mathrm{m})$ was larger than those of pumice shards $(130 \mu \mathrm{m})$ and phenocrysts $(130 \mu \mathrm{m})$ (Figure 5B; Table 1). The degree of vesicularity and stretching in pumice shards ranged from moderate to high, without compositional bands (Figure 5B; Table 1). Coarse-grained B-KY1 tephra (maximum bubble-wall shard grain size, $210 \mu \mathrm{m}$ ) in the 20EEZ-1 core mainly comprised pumice shards, with fewer bubble-wall shards and phenocrysts (Table 1). $\mathrm{SiO}_{2}$ was widely scattered, from 66.59 to 75.36 wt.\% (Figure 6; Table 2). The total alkali content (8.59-10.64 wt.\%) was slightly lower at higher $\mathrm{SiO}_{2}$ values (Figure 6). B-KY1 tephra ranged from alkaline trachyte to sub-alkaline rhyolite in the TAS diagram (Figure 6; Table 2). $\mathrm{SiO}_{2}$ content (66.59-75.36 wt.\%) in the ODP 794A core was similar among the other Baekdusan tephras, including B-Tm tephras (bimodal; 67.4-69.3 and 75.3-76.2 wt.\%), B-J (69.33-73.49 wt.\%), B-Sado (68.86-72.44 wt.\%), B-Ym (66.66-67.30 wt.\%), 20EEZ-1 core B-KY1 (66.39-70.0 wt.\%), B-KY2 (68.26-71.31 wt.\%), and B-Og (65.2-65.3 wt.\%) (Figure 6). High $\mathrm{SiO}_{2}$ content (>72 wt.\%) in B-KY1 tephra of the ODP 794A core was correlated with lower $\mathrm{Al}_{2} \mathrm{O}_{3}(9.17-11.86 \mathrm{wt} . \%), \mathrm{MgO}(0.04 \mathrm{wt} . \%$ to none detected), $\mathrm{CaO}\left(0.21-0.63\right.$ wt.\%), $\mathrm{Na}_{2} \mathrm{O}$ (3.90-5.21 wt.\%), and $\mathrm{K}_{2} \mathrm{O}$ (4.18-4.50 wt.\%) content (Figure 7B,E-H; Table 2). The FeO* content (5.48-6.05 wt.\%) of B-KY1 tephra was slightly higher when $\mathrm{SiO}_{2}$ content was high (>72 wt.\%; Figure 7C). However, $\mathrm{FeO}^{*}$ content in B-Tm (4.1-4.7 wt.\%) and B-J (4.64-5.10 wt.\%) tephras was slightly lower at high $\mathrm{SiO}_{2}$ content (Figure $7 \mathrm{C}$ ). $\mathrm{TiO}_{2}, \mathrm{MnO}$, and 
$\mathrm{Na}_{2} \mathrm{O}$ compositions showed no clear relationship with $\mathrm{SiO}_{2}$ content (Figure 7A,D,G; Table 2). The $\mathrm{CaO}$ content of B-KY1 tephra in the ODP 794A core was slightly lower than that of B-KY1 in the 20EEZ-1 core when $\mathrm{FeO}^{*}$ content was similar between the cores (Figure 8A). Based on the peralkaline classification diagram [43], B-J tephra plotted with comendite magma, whereas B-Og and B-Ym tephras plotted with comenditic trachyte magma (Figure 8B). B-Tm, B-Sado, B-KY1 (20EEZ-1 core), and B-KY2 tephras plotted with both comendite and comenditic trachyte magmas (Figure 8B). B-KY1 tephra in the ODP 794A core was widely scattered among comenditic trachyte, and comendite, as well as pantelleritic magmas (Figure 8B).
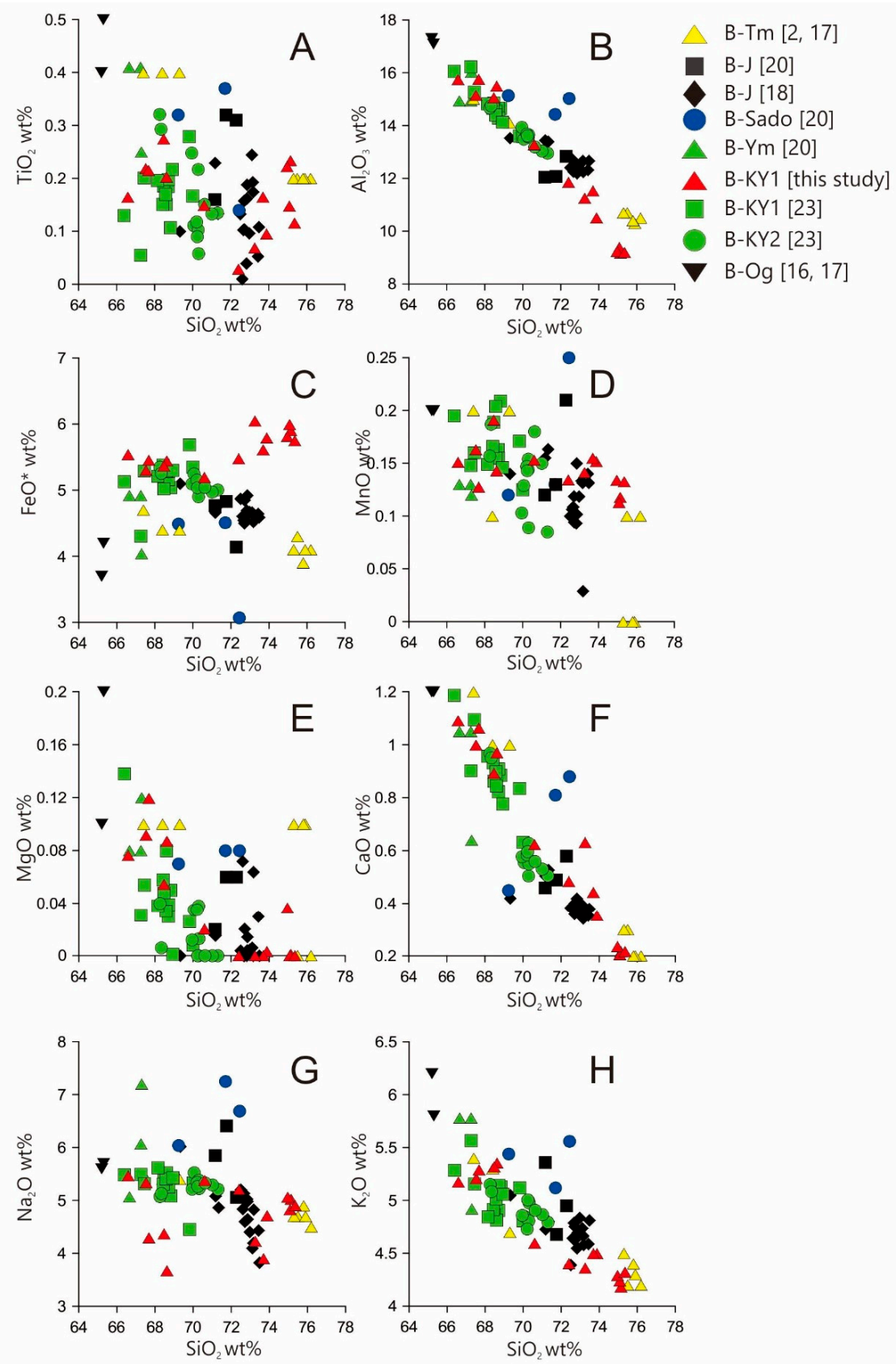

Figure 7. Major element variation diagram of selected elements versus silica from B-KY1 tephra and other Baekdusan tephra samples (Data from $[2,16-18,20,23]$ ). (A) $\mathrm{TiO}_{2}$ versus $\mathrm{SiO}_{2}$, (B) $\mathrm{Al}_{2} \mathrm{O}_{3}$ versus

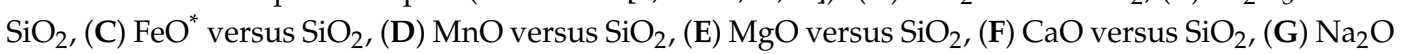
versus $\mathrm{SiO}_{2},(\mathbf{H}) \mathrm{K}_{2} \mathrm{O}$ versus $\mathrm{SiO}_{2}$. 

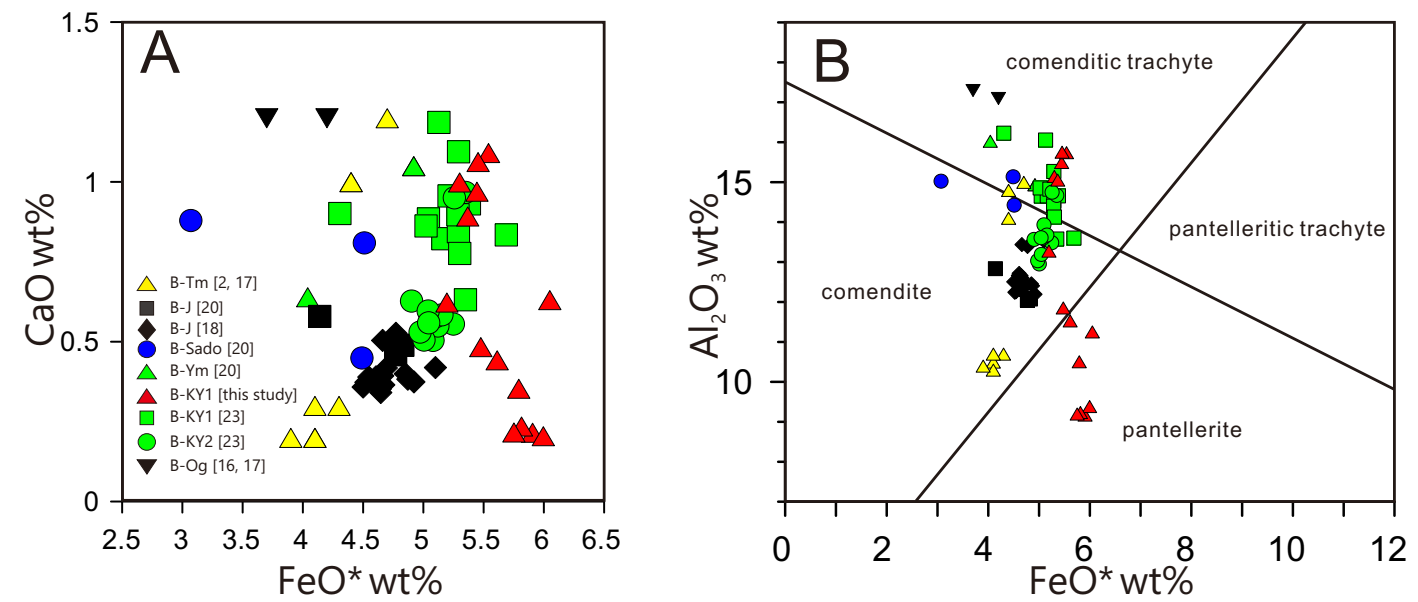

Figure 8. Major element variation diagram of B-KY1 tephra in the ODP 794A core and other Baekdusan tephra samples (Data from [2,16-18,20,23]). (A): Ca versus $\mathrm{FeO}^{*},(\mathbf{B})$ : $\mathrm{Al}_{2} \mathrm{O}_{3}$ versus $\mathrm{FeO}^{*}$ (Peralikine classification diagram adapted from [41]).

\subsection{Middle Pleistocene Aso-1 Tephra}

Stratigraphically identified Aso-1 tephra was found within LBM at an interval 802.9-803.7 cmbsf (ODP 794A 2H-2, 16.9-17.7 cm) in the ODP 794A core (Figure 4D). Pale brown Aso-1 tephra mainly consisted of bubble-wall shards, with fewer phenocrysts and minor pumice shards (Figure 5C; Table 1). The maximum grain size of bubble-wall shards $(250 \mu \mathrm{m})$ was larger than those of pumice shards $(140 \mu \mathrm{m})$ and phenocrysts $(140 \mu \mathrm{m})$ (Figure 5C; Table 1). The degree of stretching in bubble-wall shards ranged from moderate to high, whereas the degree of vesicularity ranged from low to moderate (Figure 5C; Table 1). The $\mathrm{SiO}_{2}$ content ranged from 69.68 to $70.62 \mathrm{wt} . \%$ and total alkali content $\left(\mathrm{Na}_{2} \mathrm{O}+\right.$ $\mathrm{K}_{2} \mathrm{O}$ ) ranged from 7.34 to $8.65 \mathrm{wt}$.\% (Table 2). Aso-1 tephra plotted with sub-alkali rhyolite in the TAS diagram (Figure 6). The $\mathrm{FeO}^{*}$ content was relatively high (2.59-2.93 wt.\%), and $\mathrm{CaO}$ content was also enriched (1.73-1.96 wt.\%) (Table 2).

\section{Discussion}

In this study, we characterized the B-KY1 tephra between the Toya (ca. $106 \mathrm{ka}$ ) and Aso-1 (ca. $255 \mathrm{ka}$ ) tephras in the ODP 794A core, which was collected from the Japan Basin of the East Sea/Japan Sea. Stratigraphically, the B-KY1 tephra is located between underlying DLM and overlying LBM (Figure 4C), in exactly the same stratigraphic position as the B-KY1 tephra that was first identified in the 20EEZ-1 core from the Kita-Yamato Trough (Figure 9). A pale brown B-KY1 tephra in the ODP 794A core showed a wide range of $\mathrm{SiO}_{2}(66.59-75.36 \mathrm{wt} . \%), \mathrm{Al}_{2} \mathrm{O}_{3}(9.17-15.76 \mathrm{wt} . \%), \mathrm{CaO}(0.21-1.09 \mathrm{wt} . \%)$, $\mathrm{Na}_{2} \mathrm{O}$ (4.23-5.47 wt.\%), and $\mathrm{K}_{2} \mathrm{O}$ content (4.18-5.35 wt.\%), and high $\mathrm{FeO}^{*}$ content (5.20-6.05 wt.\%). In the B-KY1 tephra, high $\mathrm{SiO}_{2}$ content was correlated with less $\mathrm{Al}_{2} \mathrm{O}_{3}, \mathrm{CaO}$, and $\mathrm{Na}_{2} \mathrm{O}$, and slightly more $\mathrm{FeO}^{*}$ (Figure $7 \mathrm{C}$ ). The elevated $\mathrm{FeO}^{*}$ content remains open to interpretation. However, the geochemical characters of B-KY1 tephra in the ODP 794A core distinguished it from Aso-4 (88 ka; Figure 5D), Toya, and Aso-1 tephras, which erupted from Japanese volcanoes (Figure 6). The B-KY1 tephras from the ODP 794A and 20EEZ-1 cores showed different textural characteristics (Table 1). To the south of Baekdusan, mixtures of coarse-grained pumice shards and bubble-wall shards were transported to the 20EEZ-1 coring site of the Kita-Yamato Trough. In the B-KY1 tephra layer of the ODP 794A core, relatively fine-grained bubble-wall shards were dominantly transported to the north of Baekdusan, perhaps reflecting changing wind patterns during the late Middle Pleistocene B-KY1 Baekdusan volcanic eruption. Shifts in wind direction can influence the distribution of tephra during its long-range transportation by explosive volcanic eruption [44]. Density separation due to greater distance from Baekdusan may also have contributed to the distribution pattern of B-KY1 tephra in the East Sea. Previous studies have concluded that explosive volcanic eruptions of Baekdusan are 
caused by comendite or comenditic trachyte magma [1,2,8,18], whereas B-KY1 tephra in the ODP 794A core originated from comendite, comenditic trachyte, and pantelleritic magmas (Figure 8B). The high $\mathrm{SiO}_{2}$ content (>72 wt.\%) of B-KY1 tephra in the ODP 794A core was correlated with lower $\mathrm{Al}_{2} \mathrm{O}_{3}$ content (9.17-11.86 wt.\%), indicating the presence of pantelleritic magma. However, B-KY1 tephra in the 20EEZ-1 core was composed of comendite and comenditic trachyte magma, without pantelleritic magma (Figure $8 \mathrm{~B}$ ). This wide range of magma types may be the results of a compositionally zoned magma chamber [44,45] or magma mixing/mingling [44,46,47]. Pumices in the Upper Pollara eruption in Italy showed a heterogeneous $\mathrm{SiO}_{2}$ composition (61-76 wt.\%) due to mixing/mingling of andesite and rhyolite [46]. Even magma mixing between two andesite magmas can cause light and dark volcanic glass, the former having greater $\mathrm{SiO}_{2}, \mathrm{~K}_{2} \mathrm{O}$, and $\mathrm{FeO}^{*}$ content, and less $\mathrm{CaO}$ and $\mathrm{Al}_{2} \mathrm{O}_{3}$ [47]. Recently, zircon isochron ages from Holocene pyroclastic deposits on Baekdusan suggested the occurrence of episodic magma generation at $110-130 \mathrm{ka}$ and $>230 \mathrm{ka}[11,27,28]$. This indicates subsequent mixing of comendite and comenditic trachyte magma with injected pantelleritic magma during the late Middle Pleistocene Baekdusan volcanic eruption.

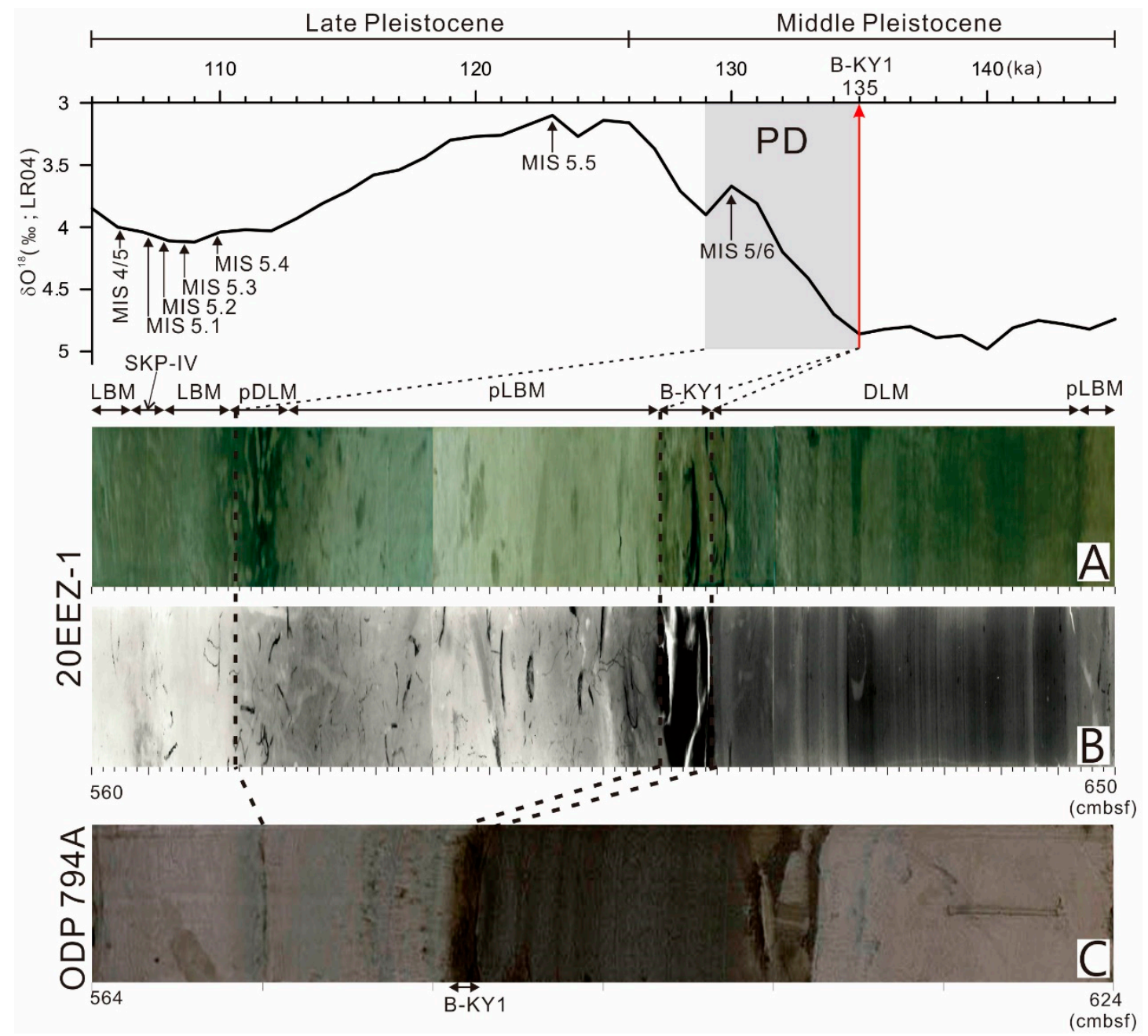

Figure 9. Improved eruption age estimate (ca. $135 \mathrm{ka}$ ) based on B-KY1 tephra and distinct sedimentary facies coinciding with the start of the penultimate deglaciation. (A) Photograph of the 20EEZ-1 core, (B): X-radiograph of the 20EEZ-1 core, (C): Photograph of ODP 794A core, MIS: Marine isotope stage, PD: Penultimate deglaciation, LBM: light bioturbated mud, DLM: dark bioturbated mud, $\mathrm{cmbsf:} \mathrm{cm}$ below seafloor.

In the present study, we compared sedimentary facies against eustatic sea level fluctuation records to refine the eruption age of B-KY1 tephra. X-radiographs of DLMs in the 20EEZ-1 core reflect 
euxinic bottom water conditions during lowstand (Figure 9). The B-KY1 tephra directly overlies DLM sedimentary facies, with a sharp lower boundary. Overlying a pyritized LBM (pLBM) has been interpreted to indicate deglaciation, consistent with restricted bottom water circulation [26]. SKP-IV tephra was found within LBM in both cores examined in this study, 20EEZ-1 and ODP 794A (Figure 9), suggesting that the B-KY1 tephra was synchronously deposited in marine sediment at the start of the penultimate deglaciation at ca. $135 \mathrm{ka}$. Further marine tephrochronological studies should facilitate further reconstruction of the explosive eruption history of Baekdusan. Bidirectional research linking Baekdusan pyroclastic deposits and distal marine tephras may improve our understanding of explosive volcanic eruptions and their climatic implications.

\section{Conclusions}

The B-KY1 tephra, located between the Toya (ca. $106 \mathrm{ka}$ ) and Aso-1 (ca. $255 \mathrm{ka}$ ) tephras in the ODP 794A core from the Japan Basin of the East Sea, was transported about $900 \mathrm{~km}$ from Baekdusan at ca. $135 \mathrm{ka}$. The stratigraphic position of the B-KY1 tephra correlates exactly with the first B-KY1 tephra identified in the 20EEZ-1 core from the Kita-Yamato Trough. The B-KY1 tephra is characterized by diverse comendite, comenditic trachyte, and pantelleritic magmas, reflecting magma generation during late Middle Pleistocene Baekdusan volcanic eruptions. Differences in geochemical and textural characteristics between the B-KY1 tephras from the ODP 794A and 20EEZ-1 cores indicate that wind directional shift influenced tephra distribution during its long-range transportation. Plinian explosive volcanic eruptions from Baekdusan may have occurred frequently during the effusive cone construction stage during the Pliestocene. Further research linking proximal terrestrial pyroclastic deposits and distal marine sediment tephras should allow us to reconstruct the explosive volcanic history of Baekdusan.

Author Contributions: Conceptualization, Formal analysis, writing-original draft, writing-review and editing, J.-H.C.; data curation, writing-review and editing, D.C. All authors have read and agreed to the published version of the manuscript.

Funding: This research was funded by Ministry of Oceans and Fisheries (MOF), Korea (project entitled "International Ocean Discovery Program", by Korea Institute of Geoscience and Mineral Resources).

Acknowledgments: This research was supported by the K-IODP project (International Ocean Discovery Program) funding from Ministry of Oceans and Fisheries, Korea. The tephra analysis was supported by project "Tephrochronology on ODP Site 794A and explosive volcanic activity of the Baekdusan" of the Kangwon National University. We thank Lee, Y.S. and Kim, B.C. for their assistance of tephra sampling from the ODP 794A core. We are grateful to two anonymous reviewers for improving the manuscript with their valuable comments.

Conflicts of Interest: The authors declare no conflict of interest.

\section{References}

1. Machida, H.; Aria, F. Extensive ash falls in and around the Sea of Japan from large late Quaternary eruptions. J. Volcanol. Geotherm. Res. 1983, 18, 151-164. [CrossRef]

2. Furuta, T.; Fujioka, K.; Arai, F. Widespread submarine tephras around Japan-Petrographic and chemical properties. Mar. Geol. 1986, 72, 125-142. [CrossRef]

3. Wei, H.; Liu, G.; Gill, J. Review of eruptive activity at Tianchi volcano, Changbaishan, northeaste China: Implications for possible future eruptions. Bull. Volcanol. 2013, 75, 706. [CrossRef]

4. Horn, S.; Schmincke, H.-U. Volatile emission during the eruption of Baitoushan volcano (China/North Korea) ca. 969 ADD. Bull. Volcanol. 2000, 61, 537-555. [CrossRef]

5. Wei, H.; Wang, Y.; Jin, J.; Gao, L.; Yun, S.-H.; Jin, B. Timescale and evolution of the intracontinental Tianchi volcanic shield and ignimbrite-forming eruption, Changbaishan, Northeast China. Lithos 2007, 96, 315-324. [CrossRef]

6. Sun, C.; Liu, J.; You, H.; Nemeth, K. Tephrostratigraphy of Changbaishan volcano, northeast China, since mid-Holocene. Quat. Sci. Rev. 2017, 177, 104-119. [CrossRef] 
7. Chen, X.Y.; Blockley, S.P.E.; Tarasov, P.E.; Xu, Y.G.; McLean, D.; Tomlinson, E.; Albert, P.G.; Liu, J.; Muller, S.; Wagner, M.; et al. Clarifying the distal to proximal tephrochrology of the Millennium (B-Tm) Eruption, Changbaishan, northeast China. Quat. Geochronol. 2016, 33, 61-75. [CrossRef]

8. McLean, D.; Albert, P.G.; Nakagawa, T.; Staff, R.A.; Suzuki, T.; Smith, V.C. Identification of the Changbaishan 'Millennium' (B-Tm) eruption deposit in the Lake Suigetsu (SC06) sedimentary archive, Japan: Synchronization of hemispheric-wide palaeoclimte archive. Quat. Sci. Rev. 2016, 150, 301-307. [CrossRef]

9. Oppenheimer, C.; Wacker, L.; Xu, J.; Galvan, J.D.; Stoffel, M.; Guilet, S.; Corona, C.; Sigl, M.; Cosmo, N.D.; Hajdas, I.; et al. Multi-proxy dating the 'Millennium Eruption' of Changbaishan to late 946 CE. Quat. Sci. Rev. 2017, 158, 164-171. [CrossRef]

10. Hughes, P.D.M.; Mallon, G.; Brown, A.; Essex, H.J.; Stanford, J.D.; Hotes, S. The impact of high tephra loading on late-Holocene carbon accumulation and vegetation succession in peatland communities. Quat. Sci. Rev. 2013, 67, 160-175. [CrossRef]

11. Pan, B.; Silva, S.L.; Xu, J.; Chen, Z.; Miggins, D.P.; Wei, H. The VEI-7 millennium eruption, ChangbaishanTianchi volcano, China/DPRK: New field, petrological, and chemical constrains on stratigraphy, volcanology, and magma dynamics. J. Volcanol. Geotherm. Res. 2017, 343, 45-59. [CrossRef]

12. Sun, C.; Plunkett, G.; Liu, J.; Zhao, H.; Sigl, M.; McConnell, J.R.; Pilcher, J.R.; Vinther, B.; Steffensen, J.P.; Hall, V. Ash from Changbaishan Millennium eruption recorded in Greenland ice: Implications for determining the eruption's timing and impact. Geophys. Res. Lett. 2014, 41, 694-701. [CrossRef]

13. Ramos, F.C.; Wolff, J.A.; Buettner, J.E.; Wie, H.Q.; Xu, J. Ra/Th ages of sanidine in young trachytes erupted at Changbaishan Volcano, China. J. Volcanol. Geotherm. Res. 2019, 374, 226-241. [CrossRef]

14. Yi, J.; Wang, P.-J.; Shan, X.-L.; Wang, H.-F.; Sun, S.; Chen, H. Lahar deposits generated after the Millennium eruption of the Changbaishan Tianchi volcano in the Erdaobaihe river system, China. J. Volcanol. Geotherm. Res. 2019, 380, 1-18. [CrossRef]

15. Okuno, M.; Torii, M.; Yamada, K.; Shinozuka, Y.; Danhara, T.; Gotanda, K.; Yonenbu, H.; Yasuda, Y. Widespread tephras in sediments from lake Ichi-no-Megata in northern Japan: Their description, correlation and significance. Quat. Int. 2011, 246, 270-277. [CrossRef]

16. Shirai, M.; Tada, R.; Fujioka, K. Identification and chronostratigraphy of middle to upper Quaternary marker tephras occurring in the Anden coast based on comparison with ODP cores in the Sea of Japan. Quat. Res. 1997, 36, 183-196, (In Japanese with English abstract). [CrossRef]

17. Machida, H.; Arai, F. Atals of Tephra in and Around Japan, revised ed.; University Tokyo: Tokyo, Japan, 2003; p. 336. (In Japanese)

18. Chun, J.-H.; Cheong, D.; Lee, Y.-J.; Kwon, Y.-I.; Kim, B.-C. Stratigraphic implications as a time marker of the B-J tephra erupted from Baegdusan volcano discovered in the marine cores of the East sea/Japan Sea during the late Pleistocene. J. Geol. Soc. Korea 2006, 42, 31-42, (In Korean with English abstract).

19. Ikehara, K. Late Quaternary seasonal sea-ice history of the north-eastern Japan Sea. J. Oceanogr. 2003, 59, 585-593. [CrossRef]

20. Lim, C.; Toyoda, K.; Ikehara, K.; Peate, D.W. Late Quaternary tephrostratigraphy of Beagdusan and Ulleung volcanoes using marine sediments in the Japan Sea/East Sea. Quat. Res. 2013, 80, 76-87. [CrossRef]

21. Nagashima, K.; Tada, R.; Tani, A.; Sun, Y.; Isozaki, Y.; Toyoda, S.; Hasegawa, H. Millennial-scale oscillations of the westerly jet path during the last glacial period. J. Asian Earth Sci. 2011, 40, 1214-1220. [CrossRef]

22. Ikehara, K. Marine tephra in the Japan Sea sediments as a tool for paleoceanography and paleoclimatology. Prog. Earth Planet. Sci. 2015, 2, 36. [CrossRef]

23. Chun, J.-H.; Cheong, D.; Han, S.-J.; Huh, S.; Yoo, H.-S. Tephrostratigraphy and paleoenvironments of marine core in the Kita-Yamato Trough, East Sea/Japan Sea. Econ. Environ. Geol. 2006, 39, 83-93, (In Korean with English abstract).

24. Chun, J.-H.; Han, S.-J.; Cheong, D. Tephrostratigraphy in the Ulleung Basin, East Sea: Late Pleistocene to Holocene. Geosci. J. 1997, 1, 154-166. [CrossRef]

25. Chun, J.-H.; Cheong, D.; Ikehara, K.; Han, S.-J. Age of the SKP-I and SKP-II tephras from the southern East Sea/Japan Sea: Implications for interstadial events recorded in sediment from marine isotope stages 3 and 4. Palaeogeogr. Palaeoclimatol. Palaeoecol. 2007, 247, 100-114. [CrossRef] 
26. Chun, J.-H.; Ikehara, K.; Han, S.-J. Evidence in Ulleung Basin sediment cores for a Termination II (penultimate deglaciation) eruption of the Aso-3 tephra. Quat. Res. 2004, 43, 99-112. [CrossRef]

27. Cheong, A.C.-S.; Jeong, Y.-J.; Jo, H.J.; Sohn, Y.K. Recurrent Quaternary magma generation at Baekdusan (Changbaishan) volcano: New zircon U-Th ages and Hf isotopic constraints from the Millennium Eruption. Gondwana Res. 2019, 68, 13-21. [CrossRef]

28. Zou, H.; Fan, Q.; Zhang, H.; Schmitt, A.K. U-series zircon age constraints on the plumbing system and magma residence times of the Changbai volcano, China/North Korea border. Lithos 2014, 200-201, 169-180. [CrossRef]

29. Matsu'ura, T.; Kimur, J.; Chang, Q.; Komatsubara, J. Using tephrostratigraphy and cryptotephrostratigraphy to re-evaluate and improve the Middle Pleistocene age model for marine sequences in northeast Japan (Chikyu C9001C). Quat. Geochronol. 2017, 40, 129-145. [CrossRef]

30. Liu, J.; Han, J.; Fyfe, W.S. Cenozoic episodic volcanism and continental rifting in northeast China and possible link to Japan Sea development as revealed from K-Ar geochronology. Tectonophysics 2001, 339, 385-401. [CrossRef]

31. Kuritani, T.; Kimura, J.; Miyamoto, T.; Wei, H.; Shimano, T.; Maeno, F.; Jin, X.; Taniguchi, H. Intraplate magmatism related to deceleration of upwelling asthenospheric mantle: Implications from the Changbaishan shield basalts, northeast China. Lithos 2009, 112, 247-258. [CrossRef]

32. Zhao, D.; Tian, Y.; Lei, J.; Liu, L.; Zheng, S. Seismic image and origin of the Changbai intraplate volcano in East Asia: Role of big mantle wedge above the stagnant Pacific slab. Phys. Earth Planet. Inter. 2009, 173, 197-206. [CrossRef]

33. Richard, G.C.; Iwamori, H. Stagnant slab, wet plumes and Cenozoic volcanism in East Asia. Phys. Earth Planet. Inter. 2010, 183, 280-287. [CrossRef]

34. Liu, J.-Q.; Chen, S.-S.; Guo, Z.-F.; Guo, W.-F.; He, H.-Y.; You, H.-T.; Kim, H.-M.; Sung, G.-H.; Kim, H. Geological background and geodynamic mechanism of Mt. Changbai volcanoes on the China-Korea border. Lithos 2015, 236-237, 46-73. [CrossRef]

35. Wei, F.; Xu, J.; Shangguan, Z.; Pan, B.; Yu, H.; Wie, W.; Bai, X.; Chen, Z. Helium and carbon isotopes in the hot springs of Changbaishan Volcano, northeastern China: A material connection between Changbaishan Volcano and the west Pacific plate? J. Volcanol. Geotherm. Res. 2016, 327, 398-406. [CrossRef]

36. Lei, J.; Zhao, D. P-wave tomography and origin of the Changbai intraplate volcano in Northeast Asia. Tectonophysics 2005, 397, 281-295. [CrossRef]

37. Choi, H.-O.; Choi, S.H.; Schiano, P.; Cho, M.; Cluzel, N.; Devidal, J.-L.; Ha, K. Geochemistry of olivine-hosted melt inclusions in the Baekdusan (Changbaishan) basalts: Implications for recycling of oceanic crustal materials into the mantle source. Lithos 2017, 284-285, 194-206. [CrossRef]

38. Wei, H.; Sparks, R.S.J.; Liu, R.; Fan, Q.; Wang, Y.; Hong, H.; Zhang, H.; Chen, H.; Jiang, C.; Dong, J.; et al. Three active volcanoes in China and their hazards. J. Asian Earth Sci. 2003, 21, 515-526. [CrossRef]

39. Fisher, R.V. Settling velocity of glass shards. Deep-Sea Res. 1965, 12, 345-353. [CrossRef]

40. Nelson, C.S.; Froggatt, P.C.; Gosson, G.J. Nature, chemistry, and origin of late Cenozoic megascopic tephras in Leg 90 cores from the southwest Pacific. In Initial reports DSDP, Leg 90, Noumea, New Caledonia to Wellington, New Zealand. Part 2; Blakeslee, J.H., Ed.; U.S. Printing Office: Washington, DC, USA, 1986; Volume 26, pp. 1161-1173. [CrossRef]

41. Tamaki, K.; Pisciotto, K.; Allan, J.; Alexandrovich, J.M.; Barenes, D.A.; Boggs, S.; Brumsack, H.-J.; Brunner, C.A.; Cramp, A.; Jolivet, L.; et al. 4. SITE 794. In Proceedings of the Ocean Drilling Program, Initial Reports; Stewart, N.J., Winkler, W.R., Eds.; Ocean Drilling Program Texas A\&M University: College Station, TX, USA, 1990; Volume 127, pp. 71-167. [CrossRef]

42. Le Bas, B.J.; Le Maitre, R.W.; Streckeisen, A.; Zanettin, B. A chemical classification of volcanic rocks based on the total alkali-silica diagram. J. Petrol. 1986, 27, 745-750. [CrossRef]

43. Gioncada, A.; Landi, P. The pre-eruptive volatile contents of recent basaltic and pantelleritic magmas at Pantelleria (Italy). J. Volcanol. Geotherm. Res. 2010, 189, 191-201. [CrossRef]

44. Kratzmann, D.J.; Carey, S.; Scasso, R.; Naranjo, J.-A. Compositional variations and magma mixing in the 1991 eruptions of Hudson volcano, Chile. Bull. Volcanol. 2009, 71, 419-439. [CrossRef]

45. Bacon, C.R.; Druitt, T.H. Compositional evolution of the zoned calcalkaline magma chamber of Mount Mazama, Crater Lake, Oregon. Contrib. Mineral. Petrol. 1988, 98, 224-256. [CrossRef] 
46. Rosa, R.D.; Donato, P.; Ventura, G. Fractal analysis mingled/mixed magmas: An example for the Upper Pollara eruption (Salina Island, southern Tyrhenian Sea, Italy). Lithos 2002, 65, 299-311. [CrossRef]

47. Donoghue, S.L.; Gamble, J.A.; Palmer, A.S.; Stewart, R.B. Magma mingling in an andesite pyroclastic flow of the Pourahu Member, Puapehu volcano, New Zealand. J. Volcanol. Geotherm. Res. 1995, 68, 177-191. [CrossRef] 